\title{
Exhortation in Calvin's sermon on 2 Timothy 3:16-17
}

Eric Kayayan

E mail: ekayayan@iafrica.com

Abstract:

Exhortation in Calvin's sermon on 2 Timothy 3:16-17

This article deals with the aspect of exhortation in one of John Calvin's sermons on the second letter of Paul to Timothy (2 Tim. 3:16-17). It is argued that the focus on exhortation in this sermon mainly serves three purposes: illustrating the specific "doctrina" on exhortation set forth in this Paulinian passage; defining more definitely the task of the pastor on the pulpit; dealing with the congregation like a doctor applying medicine to a sick body. Rhetorical devices (like equestrian or medical metaphors, or the use of the style of vehemence in the form of a diatribe set forth as a minidrama) are used to implement the purpose of the preacher in his parenetical application. In applying this, the lectio continua which was characteristic of Calvin's homiletical style, gains much relief and escapes the danger of a cold and neutral exposition of the Biblical text - the very danger against which Calvin warns in this sermon.

\section{The historical setting}

John Calvin's 54 sermons on 1 Timothy and 30 sermons on 2 Timothy were preached on Sundays at Saint Pierre in Geneva between 1554 and 1555, if we follow the chronology indicated by both Richard Stauffer (cf. Cottret, 1995:366), and T.H.L. Parker (1992:163). This chronology is discussed at some length by Parker in his study, entitled Calvin's Preaching, and rests on Denis Raguenier's Catalogue, as copied by Nicolas Colladon in his Vie de Calvin. Actually, Calvin's preaching on 1 Timothy started on Sunday morning, 16 September, 1554, while his first sermon on 2 Timothy is dated some seven months later, i.e. 21 April, 1555, the whole series probably completed on Sunday afternoon 11 August. Thus we have, in Calvin's typical fashion, some expository 
preaching on these two epistles over a period of eleven months $\mathbf{1}$; all in all, eighty four sermons which give us over a thousand pages in the Calvini Opera (volumes 53 and 54). It must of course be remembered that apart from Sundays, Calvin preached each weekday of alternate weeks (Parker, 1992:168). During this period, he also delivered sermons on the books Job and Deuteronomy. Occasionally, the series on 1 and 2 Timothy was interrupted by a sermon on a psalm, or, during Christmas, Easter and Pentecost festivals, on Luke chapter 2, Matthew 28 and Acts 2. The sermons on the Pastoral Epistles were published in Geneva for the first time by Conrad Badius six years after they had been preached, that is, in 15612. An English translation was published in London in 1579 (by G. Bishop and T. Woodcoke), following a dozen editions of Calvin's sermons on other matters ${ }^{3}$.

\section{Why the parenetical perspective?}

The purpose of this paper is to focus on the aspect of exhortation as illustrated in one of these sermons 4 . The following question may arise: why stressing the parenetical perspective ${ }^{5}$ within the broader homiletic framework? Several reasons, may, however, justify this choice.

- First, the Pastoral Epistles invite the preacher to insist on this aspect because of their own parenetical emphasis (see for instance passages like 1 Tim. 4:6-16; 6:11-16; 2 Tim. 1:6-8 and 13-14; 2:1-7 and $22-26 ; 3: 14$ to $4: 2$ ).

1 Cottret, 1995: 294: “L'auteur commentait l'Écriture selon le principe du commentaire linéaire (ou lectio continua)".

2 However, the two sermons preached on 1 Timothy chapter 2:5-7 and 2:8 (in 1555) were published by Jean Girard (Cottret, 1995:296, cf. note 11).

3 It may come as a surprise to many that the first two sermons of Calvin translated in English were published in Rome in 1553: "Imprinted at Rome before the castle of s.Angel, at the sign of s.Peter.Anno/M.D.Liii" thus reads the title page (Parker, 1992:188). They were translations from the Latin version of the four sermons in French, published the year before by Robert Estienne, actually the only four sermons which Calvin himself ever wanted to see published. Unless otherwise specified, the translations from French into English of all the excerpts quoted henceforth are my own translations.

4 Sermon 24 on 2 Timothy 3:16-17 (C.O. liv, p. 283-296) was delivered on Sunday afternoon, 21 July 1555 (Parker, 1992:168).

$5 \quad$ Following Millet (1992:155) we distinguish here between the protreptic style, which is an exhortation to conversion, and the parenetical style, addressed to Christians and exhorting them to live in a Christian way. Only the latter is relevant to this paper. 
- Second, historical circumstances prevailing in France and Switzerland in 1554-55 lead us to think that Calvin would strongly sense the need of his congregation to hear repeated exhortations: French refugees arriving in Geneva dramatically increased in number during this period. These refugees also spread the latest news of the rise of antiReformed persecution in their homeland6. However, Calvin's own position in Geneva was not yet secure when he started preaching the series on 1 Timothy, and addressing exhortations to himself was probably more than needed as well (cf. Parker, 1992:116)7.

- Third, in his homilies Calvin could stress the aspect of exhortation with a forcefulness, a persuasiveness which the more expository style of his commentaries did not allow 8 . The commentaries, more than the sermons, illustrate the famous Calvinian brevitas, which he himself deemed to be a characteristic of his style. This point can be illustrated by simply comparing the length of his expositions in the commentaries, with the extent to which he would preach a sermon on two verses of the same text ${ }^{9}$. In his homilies, rhetorical skills are displayed

The wealthiest would eventually be granted the status of bourgeois, a fact which led to the so-called revolution of 1555: Calvin's French supporters quickly won the majority during the election of the Grand Conseil. This signified the end of the opposition of the Conseil to Calvin's programme of reformation (cf. McGrath, 1990:121-123).

7 In the light of the Servetus affair, as well as the tension with the party of the Libertines, both contemporary to this series of sermons, it is significant to read the following appreciation made by Calvin at the beginning of his first sermon on 2 Timothy: "To be true, if one reads with care this epistle, he will find that the Spirit of God declared himself there in such a way and with such majesty and power, that one cannot but be gripped. As for me, I know that I have benefitted from this epistle at least as much as from any other book of Scripture, and that I benefit daily from it."

8 Incidentally, the distinction between the two genres appears from his pen in his commentary on 1 Timothy 3:1: "Mais nous n'avons pas délibéré de faire ici un sermon, et $\mathrm{S}$. Paul touchera derechef cette matière au chapitre suivant" (Calvin, 1991:130). This commentary was written six years before Calvin started preaching on 1 Timothy (the dedicatory epistle is dated 24 June 1548, and addressed to Edward, duke of Somerset, then tutor of the young king of England Edward VI).

9 Cf. Baldwin, 1992:127. Millet (1992:302) defines the relationship between the two genres in terms of the two faces of a same coin. With Calvin a homily is often nothing else but a commentary stressing the parenetical intentions of the text he discusses ("Calvin s'arrête constamment dans le texte qu'il commente sur les amorces de sa propre prédication homilétique, et parallèlement cette prédication homilétique n'est bien souvent qu'un commentaire qui met en valeur les intentions parénétiques du texte sur lequel elle porte (...)"). Nicole and Rapin (1984:160) in turn stress the exegetical relationship between the two genres: in his homiletic treatment of Isaiah 43:10-13, Calvin uses his commentary of 1551/1552, while also referring to other commentators. But in several places he modifies the exegesis of his commentary for pastoral reasons. 
in a way which, for instance, strongly emphasises the style of vehemence ${ }^{10}$ (with rhetorical figures such as interrogation, exclamation, hyperbole, emphasis, tacit antithesis - cf. Millet 1988:242-).

- Fourth, and in direct line with the previous point, the necessity of presenting his flock with a spur, or stimulus ${ }^{11}$, is mentioned recurrently by Calvin, whether in his commentaries or his sermons ${ }^{12}$. Teaching comes first, he tells us in his commentary on 2 Timothy 3:16, because exhortations would be of no avail if one had not first been taught; but, he also says, because doctrine alone is often quite dull, Paul adds reproof and correction ${ }^{\mathbf{1 3}}$. It is clear from a number of occurrences found in Calvin's works that exhortation is first of all understood metaphorically in terms of spurs: as we shall see with the aid of specific examples, it is the calling of the minister of the Word to spur the conscience of the faithful, after having exposed the doctrine, so that the souls would be awoken from the sleep they naturally fall into.

How do the third and fourth above-mentioned aspects of the parenetical perspective interact in Calvin's sermon on 2 Timothy 3:16-17? In the following part of the article this aspect will be explored while the rhetorical tools used in terms of construction and persuasion will also be highlighted.

10 For a complete survey of the style of vehemence in Calvin's works, see Millet, 1992:971.

11 French: "les aiguillons des exhortations et des répréhensions" (Calvin, 1991:233). The word "aiguillon" should be related to the goad of a herdsman. Latin uses the following: stimuli exhortationum et reprehensionum (cf. Parker, 1992:114).

12 Cf. for instance CO liv, p. 289: "Now (...) although everything is derived from the doctrine, it does not bring good fruit by itself, because of our laziness and dullness. Therefore there must be spurs to stick us." Cf. also Institutes (II, vii, 12; see Calvin, 1960:361): "The law is to the flesh like a whip to an idle and balky ass, to arouse it to work. Even for a spiritual man not yet free of the weight of the flesh, the law remains a constant sting that will not let him stand still." Calvin's sermon 26 on 2 Timothy 4:2-5 echoes the theme of the spur which stings those who fall asleep, while the precedence of the doctrine is also stressed: "Therefore let us note that the doctrine must always have precedence, if we want to build on a good and solid foundation" (CO, liv, p. 311). The same applies to sermon 25 on 2 Timothy 4:1-2 (CO liv, p. 298).

13 According to Millet (1988:242), Calvin distinguishes two types of discourse in the Biblical passages on which he comments: that of the mere exposition of the doctrina, and that which aims at assuring human beings of God's good will towards them, or of his threats. Figures of rhetoric abound in the second type of discourse, when the doctrina becomes an exhortation or a prayer. The composition and tone of his sermons sometimes reflect this distinction in style. 
One additional perspective is, however, needed to approach our topic properly: we should not forget that in Calvin's own assessment of persuasion in the practice of Christian preaching, the Holy Spirit plays a central role. This central role is, of course, stressed in chapter 7 of the first book of the Institutes $\mathbf{1 4}^{\mathbf{4}}$, but is repeated and applied throughout the corpus of Calvin's works ${ }^{15}$. The Spirit of God is the one who "inflames" hearts and renders them "ardent". As John Baird (1960:151) states: "Thus Calvin exhorted his people on Sundays and weekdays to yield themselves to the inner ministry of the Spirit. No one could have said with justice that Calvin failed to tell them of the ministry of the Spirit". Actually it might be fair to say that the very first exhortation which we find in Calvin's homilies is precisely to yield to the ministry of the Spirit. Wallace (1953:103) and Serene Jones (1995:27) stress the same perspective. Jones makes the following statement, central for our purpose, which is quoted at length:

The persuasive role played by scripture and the Holy Spirit, however, does not undercut the critically important role played by theologians, particularly when they utilize their own persuasive skills as rhetoricians (...) For Calvin, the eloquence of scripture, the power of the Spirit, and the rhetorical finesse of the theologian must work together to persuade and move the hearts of the faithful. The force of this particular point should not be missed: in order for faith to be nurtured by doctrine, in order for hearts to be moved by the truth of divine wisdom, the theologian must construct discourse capable of teaching, convincing, delighting, encouraging, and challenging the reader 'to know God and to do his will'. For this task, the tools of rhetoric are essential because they are, in short, the tools of persuasion. ${ }^{16}$

14 "Let this point therefore stand: that those whom the Holy Spirit has inwardly taught truly rest upon Scripture, and that Scripture indeed is self-authenticated; hence, it is not right to subject it to proof and reasoning. And the certainty it deserves with us, attains by the testimony of the Spirit" (I, vii, 5; see Calvin, 1960:80).

15 Commenting on the Pentecost narrative, Calvin writes: "It is, then, well for us, while God gives us leisure, to think carefully about this, and to practise this account which we see: namely, since the Holy Spirit descended upon those who were of one accord, may we learn to assemble ourselves, and although we are far from the front lines, nevertheless may we be joined with those who do battle, and may we help them in combat by our prayers with mouth and heart; so that the Spirit of God may be in charge of everything, and that He may inflame us with such zeal that we may be ardent to call upon our God, instead of being too cold" (CO xlviii, p. 969).

16 Cf. also Millet (1988:241): "Nous retrouvons entre autres chez Calvin, au croisement de la théologie et des catégories rhétoriques, la définition de la foi comme fiducia (cf. G. Budé, M. Bucer, Luther), l'accent mis sur l'oeuvre du Saint Esprit comme auteur, dans le coeur des fidèles, de la persuasio qu'est la foi chrétienne (...)". 


\section{Sermon on 2 Timothy 3:16-17: an exhortation to apply the proper doctrina of preaching.}

Looking at the sermon on 2 Timothy 3:16-17 (CO liv, p.288-292) it is actually quite remarkable to verify how Calvin develops his teaching on the necessity of exhortations in preaching: actually, a large part of this sermon can be seen as a parenetical section addressed to preachers to exhort the flock which has been committed to their pastoral care. A kind of double exhortation is therefore at stake here: Calvin first exposes the doctrina of sound preaching as he sees it (among others, preachers should make use of exhortations in their sermons). It inevitably leads him to publicly exhort himself as preacher, so that the flock may also know what to expect from its pastor17:

When, therefore, I expound the Holy Scripture, I always have to conform to that rule, namely that those who hear me would benefit from the doctrine which I submit to them, and that they would be edified in view of their salvation. If I do not have this desire and I do not bring about the edification of those who hear me, I am sacrilegious, only desecrating the word of God. 18

This edification, as we have seen, cannot take place without the spurs which are necessary to wake up the believers: actually, the verb "to wake up" appears thrice in different forms in the short span of the sermon's section dealing with "reproof and correction". On the other hand, for Calvin being asleep implies to forget about God in our lives.

This point being made, he proceeds from what he perceives to be God's vehemence, towards the vehemence required of ministers of the Word in their parenetical application. Following the accumulation of terms in the Paulinian text ("all scripture is inspired by God and profitable for

17 In his reply to Sadoleto (Calvin, 1998:104), Calvin describes the practice of preaching in the Roman church as follows: "For as sermons were then usually divided, the first half was devoted to those misty questions of the schools which might astonish the rude populace, while the second contained sweet stories, or not unamusing speculations by which the hearers might be kept on the alert. Only a few expressions were thrown in from the Word of God, that by their majesty they might procure credit for these frivolities."

18 Parker (1992:116) bluntly states that "there was, however, always one man in the congregation at whom he directed his sermons. And that was himself". He then proceeds by quoting from the 22nd sermon on 1 Timothy 3:1-4, where the minister of the Word is charged to submit himself first to the doctrine he preaches: "(...) he has such a reverence for the teaching he proclaims that he means to be the first to be obedient to it, and that he wishes to declare that he is not only imposing a law on others but that the subjection is in common and that it is for him to make a start" (C.O. liii:257-258, Parker's translation). 
teaching, for reproof, for correction and for training in righteousness ..."), Calvin fashions his own rhetoric on this accumulation. But, as we will notice, in so doing he tightly constructs his discourse. The inadequacy of teaching without reproving and correcting, gives him the opportunity to take his hearers on a spiritual race based on equestrian metaphors, a kind of horse-race to be taken figuratively $\mathbf{1 9}$ (a familiar image of Calvin's pen). The movement accelerates, starting from a similitude between God and a father figure angry at his disobedient children:

In the same way, when a father sees his debauched children, he is not satisfied to merely tell them: But what are you doing, my children? That is neither beautiful nor good. Rather, he will tell them: you wretched creatures, have I fed you, have I supported you up to now for you to pay me back in such a way? After I have treated you so leniently, must you bring me such great dishonour? Come, you wretch, you deserve to be handed over to the executioner, since you are worth nothing: must I feed such filth in my house? Thus it is when God sees that he has time and again put up with us, and that despite this, we are much more rebellious than children disobeying their earthly fathers. Mustn't he become heated against us so that we would be deeply shaken when we feel that he become, so to say, angry with us?

The vehemence of God thus brought forward, its goal is now being explained to the congregation in terms of taming, or subduing a horse:

Not that he [God] is subject to any passion; but he uses this vehemence in order to subdue us, that we may not act like horses in escape, and when we have wandered from him, that he may hold us back by force and that we may learn what it is to obey.

The next - central - element in this section consists of the core of the particular doctrina expounded here: namely that it is not enough to expound Scripture like a mere propositional account 20 . This element is

19 Commenting on Calvin's Annotations on Chrysostom's homilies, Millet (1992:177) notes that Chrysostom was well known for his figurative parenetical language, and that Calvin owes him a lot on this point. Of course, the particular equestrian metaphor noted here does not come from Chrysostom, but from Augustine, or PseudoAugustine (cf. footnote 3 in F.L. Battles' translation of the Institutes, II, iv, 1; see Calvin, 1960:309). Cf. also Institutes, III, viii, 5 (Calvin, 1960:705): "For the same thing happens to it that happens to mettlesome horses. If they are fattened in idleness for some days, they cannot afterward be tamed from their high spirits; nor do they recognise their rider, whose command they previously obeyed."

20 Cf. Peter (1984:25): "On connaît l'importance qu'attachait Calvin à un enseignement bien appliqué. "Une doctrine exposée en général, dit-il dans l'un de ses commentaires, ne touche pas, il faut en venir aux mains" (cf. also Schulze, 1998:115126). 
immediately followed by new metaphorical language in equestrian terms: "But he [Paul] says that there must be kicks of spurs to stick us".

The relationship between this image and the previous one presents us with the following antithesis: while a horse trying to escape and running its own course needs to be held back and subdued, that same horse, once tamed, is incited to run a course now defined and directed by its master21. Calvin can now spell out the consequence: pastors need to make use of vehemence while preaching:

Therefore the office of a good and faithful pastor is not to merely expound in order to say: Here is what it is about, but he will have to become vehement through and through, and there will have to be sharpness in order to give vigour and strength to the word of God; that is why Paul writes in another passage that the pastors of the Church should persist to the point of becoming importunate (...) and not only show what is good, but reproof and rebuke.

What then follows in that same section, is an application of the style of vehemence by the preacher, in line with the argumentation brought forward thus far. Here Calvin introduces a diatribe under the form of an antithesis presented as a mini drama: its preserved oral style gives us an adequate idea of how Calvin could enact different attitudes or reactions from the pulpit, not shunning away from invectives:

It is true that he says it should be done with gentleness and leniency, and also with patience; but whatever the case may be, corrections must follow their course. No one should come and say: Ho, that is too hard to bear, it is not the right way to deal with it. Those who cannot stand to be rebuked, let them go and look for another master than God, because they are not worthy to hear a single word from his mouth. True, the world would like to be spared, and our ears are touchy: and so we will see many who grow more acrimonious when one brings corrections and threats: What now? Is that a way to teach? Ho, we want to be won by gentleness. You want? Go then and teach God his lesson. Here are our delicate people who cannot stand a single reproof when it is put before them. And why? Ho, we want to be taught with a different style? Go to the school of the devil, for he will flatter you enough, for your own doom.

21 The same twofold image appears in the Institutes (IV, xii, 1) with a related topic, that of discipline: "Therefore, discipline is like a bridle to restrain and tame those who rage against the doctrine of Christ; or like a spur to arouse those of little inclination" (Calvin, 1960:1230). 
The antithesis with the faithful is then presented, and instead of equestrian imagery language, Calvin here uses a vivid medical metaphor22:

But as far as the faithful are concerned, after they have received the doctrine with integrity, they need to humiliate themselves, being ready to be rebuked and exhorted when they have lapsed. Their sins and offences need to be exposed; it is necessary to take the lancet in order to burst the abscess, so that the pus hidden inside would come out and that by this means they should be purged and led to complete healing. This is in sum where we must be brought to be duly taught in the school of God.

Looking back at the different elements occurring in this section, we come across the fact that in what at first seems to be a mere flow of reasons and arguments forcefully presented, we actually have a very distinct arch construction: A-B-C-B'-A'23. The movement starts with God's relationship with his children, is centred in the correct exposition of Scripture in preaching, and moves towards the preacher addressing the flock, as a direct echo of God's own speech to his creatures.

After the section on reproof and correction has been taken care of, Calvin proceeds to the next element of the Paulinian text unit: "... and for training in righteousness, that the man of God may be complete, equipped for every good work". The necessity of corrections has been demonstrated in the previous section in terms of a moral and spiritual disease which needs to be doctored with strong - even harsh medicine. Here, led by the text he expounds, Calvin offers us a larger perspective on the goal of exhortations: the life of the faithful must be reformed and bear fruit ("c'est pour reformer nostre vie, que nostre vie soit reformee"). The application of the word of God is pervasive through the whole existence of the believer. Note here the unusual perspective

22 For another example of a medical metaphor from Calvin's pen, cf. Institutes, III, 1, 3 in the French text, where the role of the Holy Spirit as a doctor restoring health is described: not only does he give medicinal "liquors", but he also boils away and burns up our inordinate desires, which are like bad internal humours (archaic medical word EK) and secretions.

23 A: God's vehemence (simile of the father angry with his debauched children);

B: goal thereof: subduing horses wanting to escape;

$\mathrm{C}$ : doctrina: it is not enough to expound propositional truth in preaching;

$B^{\prime}$ : spurs sticking us are required;

$A^{\prime}$ : consequence: in response to God's vehemence $(A)$ the vehemence of preachers is required in exhortations; immediate application in vehement style: antithesis between the rebellious (who do not want to hear this kind of exhortation; they can be identified with the debauched children in A) and the faithful, who submit to the exhortations and are eventually healed. 
(according to our modern conception) on what being a good theologian actually entails:

Besides, he meant to say that in order to be good theologians, we must lead a holy life, and that the word of God is not there to teach us to babble nor to make us eloquent or subtle, or whatever the case may be; but it is given in order to reform our lives, so that one may know that we desire to serve God, to give ourselves entirely to him and to conform to his good will. Therefore if we want to know whether someone has grown into the Gospel, let us look at his life.

The exposition on the Scriptural passage continues, now focusing on the true service of God, versus human inventions. Exhortation here takes a new dimension, amidst the flow of stings and spurs. An element of promise and comfort is now given, focused on the notion of "integrity". Calvin defines it as follows:

When he speaks of integrity, he means that we will be well-proportioned and constituted: like when a body has got all its parts, and that none is missing. The word he uses carries this meaning, namely that one will not be able to find a fault. Therefore, let us remark that as we are by nature totally perverse, God restores his image in us by way of his word, so much so that we progressively come to this integrity of which Paul speaks.

The conclusion of the sermon can be seen as a good balance between these two parenetical aspects: on the one hand an exhortation to the faithful to apply themselves to obedience and sanctification, on the other hand a reminder that God came near to them:

We must therefore apply all our thoughts, our affections and works to the content of Holy Scripture, and then, we shall be approved by the heavenly Judge; we must do it all the more as we see that our good God came near us thus, and revealed his will so much that there is no excuse left for us: we must fully adhere to him.

\section{Conclusion}

That Calvin strongly emphasised the aspect of God's imperative in his exhortations, cannot be denied. Other sermons on the Pastoral Epistles amply demonstrate it as well. Of course one cannot give a fair assessment of his parenetical approach at large on the basis of only one expository sermon (taking into consideration that aspects such as comfort or promise do not specifically come to the fore in the text discussed). Nevertheless, a tension is clearly perceptible throughout this sermon: the stings of the spurs are not only mentioned as a necessity, they are rhetorically applied to the congregation by means of various devices, at times to the point of saturation. However, they do not operate 
separately from an element of doctrine which Calvin has exposed repeatedly. This element of doctrine allows him to proceed in the application without risking to be accused that he does so arbitrarily. The scriptural doctrine is, of course, that Scripture itself declares in this passage that exhortations, in the form of reproofs and corrections, must be unequivocally applied by the preacher to his congregation. In this respect we certainly are dealing with a kind of consciously circular argument, but we still need to ask ourselves what motives could have led Calvin to insist in such a pressing way on this type of exhortation. We have just seen the first reason: within the framework of the specific text he was preaching on, he had an ideal opportunity to demonstrate in his homiletical practice, how to deal with a doctrine which can be applied elsewhere, but appears here in its matrix form, so to speak. I believe, though, that two other reasons would lead him to bring these pressing exhortations to his flock:

- At the beginning of this article, the situation of Geneva at this specific time was mentioned. Rodolphe Peter (1984:23-48) comments in depth on the question of Geneva in Calvin's preaching. For Calvin, Genevans had received an immeasurable privilege in that they could hear the pure Word of God preached to them without hindrance. They had to show themselves worthy of this privilege, and not let the outside world defame the Reformation. They were to be a light for the nations, actually not unlike Israel in the Old Testament. They also adopted the motto Post tenebra lux on their coins. Unfortunately, according to Calvin, at this specific point in time, many Genevans were doing exactly the contrary of what they should have done. Therefore, more than individual souls was at stake: actually, the fate of the whole Reformation was at stake in this respect. For the man who had set as a goal for himself to bring the Reformation to Geneva, and from there everywhere else in Europe, pressing exhortations were needed more than ever.

- Another reason, however, might weigh even more: we have noted the prominence of the doctrine of the Holy Spirit in Calvins' preaching. Because of his insistence on the ministry of the Holy Spirit, Calvin would stress sanctification in the lives of his hearers. Inescapably, the "theopneustos Word" of 2 Timothy 3:16-17 would become a sword in the hands of the preacher: a sword to be forcefully thrusted from the pulpit into the life of his congregation, not for the sake of destruction and doom but rather for the sake of healing: the careful rhetorician actually handling the word like a fine surgeon would do with a lancet. 


\section{Bibliography}

BAIRD, J.S. 1960. Preaching on the Holy Spirit in the light of the New Testament witness and the preaching-example of selected men. Philadelphia, PA : Temple University. (Thesis - D.Th.)

BALDWIN, C.-M. 1992. Marriage in Calvin's sermons. (In Gamble, R.C., ed. Articles on Calvin and Calvinism, 3. A Garland Series. New York: Garland Publishing. p. 107-115.)

CALVIN, J. 1895. Ioannis Calvini opera quae supersunt omnia (vol. liii \& liv). Braunschweig : Baum, Cunitz \& Reuss.

CALVIN, J. 1960. Institutes of the Christian Religion. Edited by John T. McNeill, translated and indexed by Ford Lewis Battles. Philadelphia : The Westminster Press.

CALVIN, J. 1991. Commentaires bibliques, épîtres aux Thessaloniciens à Timothée, Tite et Philémon. Aix-en-Provence : éditions Kérygma-Farel.

CALVIN, J. 1998. Reply to Sadolet. (In The Comprehensive John Calvin Collection. $\mathrm{CO}$ CD-ROM, version 1.0.) The AGES Digital Libraries Series : AGES Software.

see CALVIN, J. 1895.

COTTRET, B. 1995. Calvin, biographie. Paris : Lattès.

JONES, S. 1995. Calvin and the rhetoric of piety. Louisville, Ken. : Westminster/John Knox Press.

McGRATH, A.E. 1990. A life of John Calvin. Oxford : Blackwell.

NICOLE, P.-D. \& RAPIN, C. 1984. De l'exégèse à l'homilétique. Évolution entre le commentaire de 1551, les sermons de 1558 et le commentaire de 1559 sur le prophète Ésaïe. (In Calvinus Ecclesiae Genevensis Custos, die Referate des Internationalen Kongresses für Calvinforschung Vom 6. bis 9. September 1982 in Genf, herausgegeben von Wilhelm H. Neuser. Frankfurt am Main : Verlag Peter Lang. p. 159-162.)

MILLET, O. 1992. Calvin et la dynamique de la parole. Étude de rhétorique réformée. Paris : Librairie Honoré Champion.

MILLET, O. 1988. L'emploi des figures de rhétorique par Calvin - les styles de la parole calvinienne. (In Calvinus Servus Christi, die Referate des Internationalen Kongresses für Calvinforschung Vom 25. Bis 28 August 1986 in Debrecen, herausgegeben von Wilhelm $\mathrm{H}$. Neuser. Budapest : Presseabteilung des RàdayKollegiums. p. 241-244.)

PARKER, T.H.L. 1992. Calvin's preaching. Louisville, Ken. : Westminster/John Knox Press.

PETER, R. 1984. Geneva dans la prédication de Calvin. (In Calvinus Ecclesiae Genevensis Custos, die Referate des Internationalen Kongresses für Calvinforschung Vom 6. bis 9. September 1982 in Genf, herausgegeben von Wilhelm H. Neuser. Frankfurt am Main : Verlag Peter Lang. p. 23-48.)

SCHULZE, L.F. 1998. Preaching as topical communication: The case of Calvin. In die Skriflig, 32(2):115-126.

WALLACE, J. 1953. Calvin's doctrine of the Word and sacrament. Grand Rapids, Mi : Eerdmans. 


\section{Keywords:}

Calvin; rhetoric

Calvin; sermons: exhortation

exhortation (2 Tim. 3:16-17); Calvin's sermons

\section{Kernbegrippe:}

Calvyn; preke: vermaning

Calvyn; retoriek

vermaning (2 Tim. 3:16-17); Calvyn se preke 
